\title{
SCIENTIFIC AND TECHNICAL FUNDAMENTALS FOR EXPLOSIVE DESTRUCTION OF THE MASS COMPOSED OF ROCKS WITH DIFFERENT HARDNESS
}

\author{
Sh. Zairov ${ }^{1}$, M. Ravshanova ${ }^{1 *}$, Sh. Karimov ${ }^{1}$ \\ ${ }^{1}$ Mining Faculty, Navoiy State Mining Institute, Navoiy, Republic of Uzbekistan \\ *Corresponding author: e-mail m ravshanova@mail.ru, tel.+998933141054
}

\section{НАУКОВО-ТЕХНІЧНІ ОСНОВИ ВИБУХОВОГО РУЙНУВАННЯ МАСИВУ РІЗНОМЦНИХ ГІРСЬКИХ ПОРІД}

\author{
Ш. Заіров ${ }^{1}$, М. Равшанова ${ }^{1 *}$, Ш. Карімов ${ }^{1}$ \\ ${ }^{1}$ Гірничий Факультет, Навоїиський державний гірничий інститут, Навої, Республіка Узбекистан \\ *Bidnовідальний aвmop: e-mail m ravshanova@mail.ru, mел.+998933141054
}

\begin{abstract}
Purpose. To develop the technology for explosive destruction of solid inclusions in the mass of rocks with different hardness on the basis of established correlations between changes in the radius of hard streaks fragmenting, fracturing density and relative distance to the free surface during various initiating techniques in rocks of different hardness.

Methods. Theoretical and experimental research into the development of scientific and technical fundamentals of explosive destruction of the mass of rocks with different hardness, which allows to determine the zone of hardening soft rocks located between solid inclusions.

Findings. The developed technology for explosive destruction of mass of rocks with different hardness was implemented in the Tashkura quarry of Dzheroj-Sardara phosphate deposit of Navoiy MMC resulting in the economic effect of UZS $581.7 \mathrm{mln}$ per $10.5 \mathrm{mln} \mathrm{m}^{3}$ of the extracted rock, while the economic effect in the free industrial and economic zone "Navoiy" was more than UZS $12 \mathrm{mln}$ per $17000 \mathrm{~m}^{3}$ of the extracted rock.

Originality. The conducted complex research resulted in the new technology for explosive destruction of the mass of rocks with different hardness, including hole boring, determination of the number and capacity of hard streaks in the process of boring, placing of the explosive charge in the hole, stemming. and blasting.

Practical implications. Implementing the research results in the open quarry of Navoiy MMC allowed to make a significant contribution to the solution of the topical scientific and practical problem: efficient blast energy utilization during industrial explosions on hard streaks.
\end{abstract}

Keywords: rock, rock mass, fragmentation, rocks with different hardness, stress field

\section{INTRODUCTION}

One of the most power-intensive processes of mining is the explosive preparation of rock mass, which in many respects defines the efficiency and cost of production. Results of the whole technological complex performance depend on the quality of explosion preparation.

The blown-up rocks of the fields with difficult structure are characterized by heterogeneity of physical and mechanical properties, intensive jointing, blockiness, and hard streaks. Rock masses differ in strength and acoustic rigidity, thus during the explosion of borehole charges, the main part of explosion energy is spent on consolidation of soft rocks, and only insignificant part of energy is spent directly on loosening hard streaks.
It should be noted that the existing methods of industrial explosive works conducted in rocks of different hardness are characterized by post-explosion formation of upheaving sections with cracks and slips, and the subsequent development of these blocks shows poor quality of the mass loosening due to appearance of hollows in the form of chambers (Norov, Bibik, \& Zairov, 2016). The known ways of explosive destruction of the mass composed of rocks with different hardness do not provide uniform fragmenting of hard streaks, which leads to deterioration of rock preparation and increase in excavation costs. When studying processes of explosive destruction of the mass of rocks with different hardness from the fields of difficult structure with application of borehole explosives charges, it is necessary to pay special attention to detection of physical features of their destruction de- 
pending on concrete structural and strength properties of the rock mass to be blasted (Norov, Zairov, Xaydarov, \& Rustamov, 2016).

The above considerations allowed to formulate the scientific problem related to development of scientific and technical fundamentals of explosive destruction of the mass of rocks with different hardness. This will make possible to define the methods of uniform fragmenting due to the effective use of explosion energy on hard streak.

During explosive destruction of the mass of rocks with different hardness the main part of explosion energy is spent on consolidation of soft rocks with formation of a gas cavity, and only insignificant portion of energy is spent directly on loosening hard streaks.

\section{THE MAIN PART OF THE ARTICLE}

The research into propagation of explosive waves in the rocks with different hardness allowed to develop a mathematical model simulating the action of cylindrical and spherical explosive charges in masses composed of soft rocks and hard streaks, which made it possible to determine the zone of soft rocks consolidation located between hard streaks (Norov, Zairov, \& Sattarov, 2013).

Regularity of stress $\sigma_{r}$ and deformation $\varepsilon$ change depending on the distance in the mass of rocks with different hardness is determined by the formulas:

$$
\begin{aligned}
& \sigma_{r}=K_{\sigma}\left(\frac{x}{r_{0}}\right)^{-\mu_{\sigma}} ; \\
& \varepsilon=k_{\varepsilon}\left(\frac{x}{r_{0}}\right)^{-\mu_{\varepsilon}},
\end{aligned}
$$

where:

$K_{\sigma}$ - coefficient of stress change on the wave front in respect to the distance, $\mathrm{Pa}$;

$x$-distance from the center of charge symmetry to the set point;

$r_{0}$ - radius of a cylindrical charge;

$\mu_{\sigma}$-indicator of the degree of deformations attenuation in the wave in respect to the distance from explosion;

$k_{\varepsilon}$ - coefficient of deformations change in respect to the distance;

$\mu_{\varepsilon}$ - indicator of the degree of deformations attenuation in the wave in respect to the distance from explosion.

Taking into account the linear density of the cylindrical charge:

$\Delta_{l}=\pi r_{0}^{2} \rho=\pi \rho h^{2}\left(\frac{\varepsilon_{k}}{k_{\varepsilon}}\right)^{\frac{2}{\mu_{\varepsilon}}}$,

where:

$\Delta_{l}-$ linear density of the cylindrical charge, $\mathrm{kg} / \mathrm{m}^{3}$;

$\rho$ - density of the explosive, $\mathrm{kg} / \mathrm{m}^{3}$;

$\varepsilon_{k}$ - deformation to which soft rock is consolidated;

$h$ - depth of soft rock consolidation, $\mathrm{m}$.

The formula which includes the key parameters defining the physical and mechanical properties of soft rock and coefficients defining attenuation of the explosive wave in the soft rock mass is developed.
It is established that when the a cylindrical charge is exploded in rocks with different hardness, rigid walls are formed in soft rocks. The depth of their consolidation is determined by the formula:

$h=r_{0}\left[\frac{\rho k_{\varepsilon}}{\rho-\gamma\left(1+0.01 W_{g}\right)}\right]^{\frac{1}{\mu_{\varepsilon}}}$,

where:

$h$ - depth of soft rock consolidation, m;

$\rho$ - density of soft rock, $\mathrm{kg} / \mathrm{m}^{3}$;

$\gamma$-density of soft rock skeleton, $\mathrm{kg} / \mathrm{m}^{3}$;

$W_{g}$ - soft rock moisture content, u.f.

With increase in the radius of the cylindrical charge and mass moisture, the depth of soft rock consolidation zone increases, and with increase in soft rock density the zone of consolidation decreases. Changing depth of various soft rocks consolidation zone during the explosion of borehole charges is given in Figure 1 in relation to the radius of the cylindrical charge, mass moisture and density of soft rock.

(a)

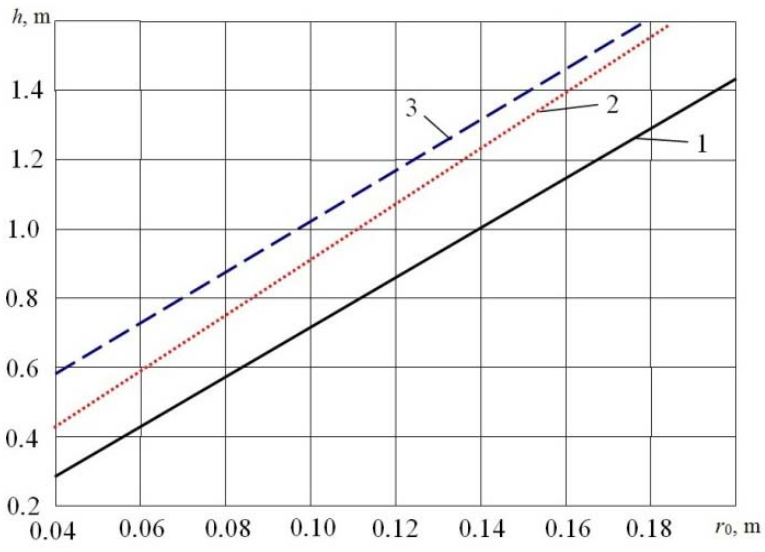

(b)

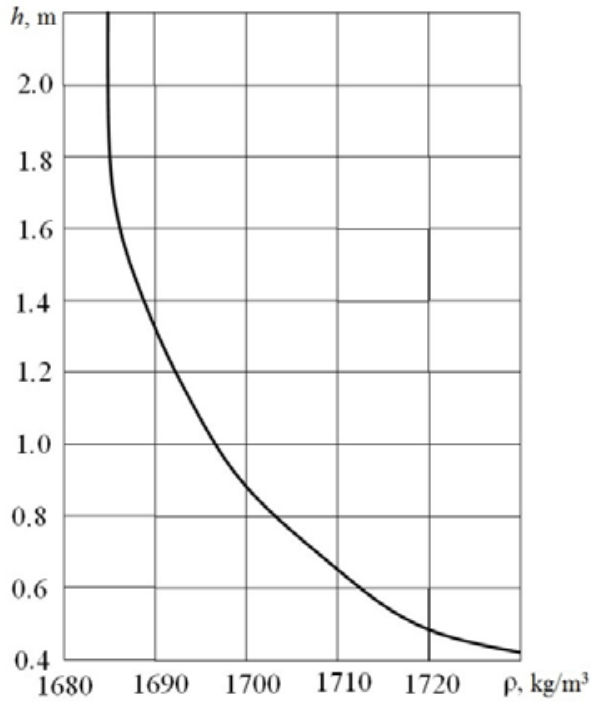

Figure 1. Changing depth of soft rocks consolidation zone during the explosion of borehole charges depending on the radius of the cylindrical charge ro (a) and soft rock density $\rho$ (b): 1 - loam; 2 - sandy loam; 3 -sand 
The developed algorithm and software became the basis for calculating soft rock consolidation by borehole explosive charges and determining parameters of drilling-and-blasting works during fragmentation of solid inclusions in the rocks with different hardness. For calculating consolidation depth of soft rocks located between solid inclusions by explosions of the cylindrical charge we suggested a formula which includes the key parameters describing the physical and mechanical properties of soft rocks and coefficients defining attenuation of the explosive wave in the soft rock mass.

It is established that during the explosion of the concentrated charge in unbounded solid medium, the products of explosion are reflected from the medium adjacent to the charge, which, possessing considerable inertia, starts moving only after some time. During this time, products of explosion are repeatedly reflected. For this reason, their pressure upon the solid medium is leveled in all directions from the center of the charge and therefore such charge can be considered spherical.

The size of mass $R$ destruction zone in the rocks with different hardness changes directly proportionally to charge radius $R_{0}$, power indicators of industrial explosives and inversely proportional to the critical speed of rock particles scattering $v_{c r}$ :

$$
R=\frac{R_{0} \sqrt{\frac{\gamma Q}{\Delta}}}{0.625 \sqrt{v_{c r}}},
$$

where:

$\gamma$ - volume weight of explosives, $\mathrm{kg} / \mathrm{m}^{3}$;

$Q$ - energy of a weight unit of explosive substances, $\mathrm{kgm} / \mathrm{kg}$;

$\Delta$ - volume weight of rock in natural state, $\mathrm{kg} / \mathrm{m}^{3}$.

Change of radius of hard streaks fragmentation by explosion of a spherical charge in linear dependence on the charge radius, volume weight of explosives, and also parabolic dependence on the rock volume weight in natural state and energy of a unit of explosives' weight is given in Figure 2.

The processes accompanying the explosion by group detonation of borehole explosive charges in the rocks with different hardness have been studied. Considering interaction of stress waves during the explosion of two borehole explosive charges, we established that during the inverse initiation, the best rocks fragmentation is achieved in the time lapse between charges of more than $40 \mathrm{~ms}$, and for direct initiation - the best fragmentation of rocks is accomplished during simultaneous detonation of the group of charges.

The effective distance between intermediate detonators during direct initiation of borehole explosive charges in relation to speeds of industrial explosive $v_{2}$ detonation and detonator $v_{1}$, as well as the distance from the lower detonator to the set depth of detonation waves meeting $l$ is defined as:

$$
a=\frac{2 l}{1-\frac{v_{2}}{v_{1}}} \text {. }
$$

(a)

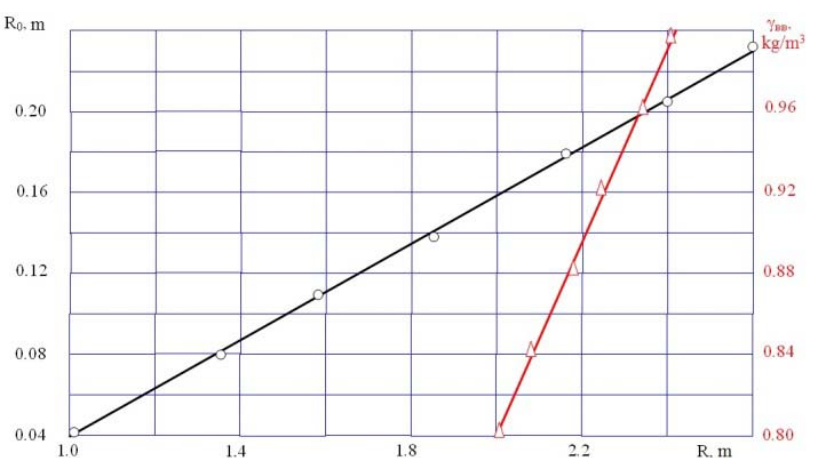

(b)

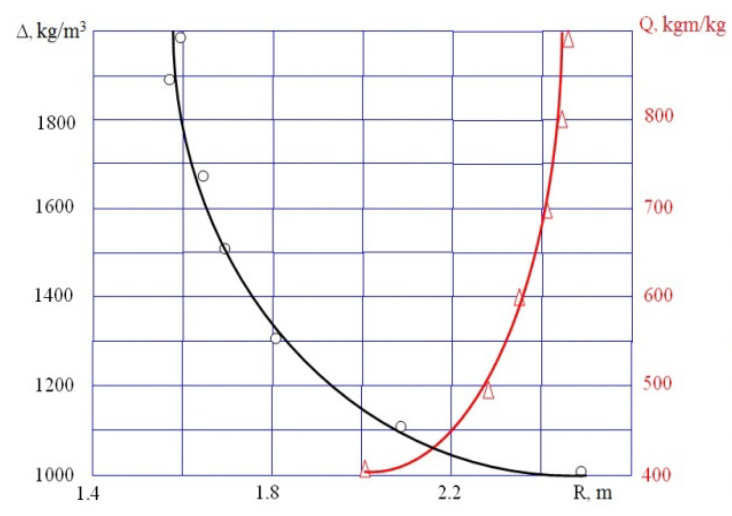

Figure 2. Changing radius $R$ of hard streak fragmentation by explosions of the spherical charge depending on the charge radius $R_{0}$ and volume weight of explosives $\gamma(a)$, as well as on the volume weight of rock in natural state $\Delta(\circ)$ and the energy of explosive weight unit $Q$ (b)

A mathematical method is developed for calculating the stress field in a hard streak of the rocks with different hardness in the fixed point at the set moment, which allows to determine the effective radius of the blast action during direct initiation of a borehole explosive charge.

Experimental research into the impact of borehole explosive charges blast in the rocks with different hardness involved two-stage physical modeling. During the first stage, stress waves parameters were investigated considering various ways of borehole explosive charges initiation in the rocks with different hardness, and in the second stage, uniformity of their fragmenting. was studied.

For the experiment of the first stage, we chose the sites of rocks with different hardness on Tashkura quarry of Dzheroj-Sardara phosphate deposit where it was possible to maintain parameters of drilling-and-blasting works to determine the value of stress impulse propagated into the mass, and to assess visually the blast quality.

The experiments were conducted in the following way. The scale of modeling was increased 1:7. The holes with a diameter of $36 \mathrm{~mm}$ were drilled by the PR-19 drill-press, the charge - stick powder ammonite No 6JV (32 $\mathrm{mm}$ diameter) with specific consumption of $0.5-0.6 \mathrm{~kg} / \mathrm{m}^{3}$. The borehole charges were stemmed with subsoil, blasting was done by instantaneous electrodetonators ED-8J with the igniter KPM-1A. 
The works were carried out according to two schemes of detonation. The first scheme involved drilling of holes in a hard streak (gritstone layer) $1 \mathrm{~m}$ long with overdrilling in soft rock layer $0.3 \mathrm{~m}$ long. We used the blast of continuous column design with inverse initiation by one electrodetonator. According to the second scheme, holes were drilled in a continuous hard streak of gritstone with underdrilling $0.15 \mathrm{~m}$. The charge in this case was of continuous column design with the counter-directed (top and bottom) initiation by two electrodetonators.

To measure the explosive impulse of the shock wave from each blown-up experimental block at distances $50 \ldots 100 r_{z a r}$ (where $r_{z a r}$ the radius of a borehole charge), i.e. three holes (1, 2 and $3 \mathrm{~m}$ ) were drilled for installation of sensors ( $250 \mathrm{~mm}$ diameter and $0.5 \mathrm{~m}$ deep) registrating the pulse signal by sensors SV-10C.

Registering impulses of stress in the chosen direction from a place of explosion and measuring their parameters provided information on the efficiency of the conducted explosion.

When compared, impulses amplitudes differ approximately by two times. The difference of impulses in terms of both duration, and amplitude shows that they strongly differ in the area under impulse curves which veritably reflect the experimentally observed waves of stress in a mass. Researches proved the possibility of identifying explosions conducted with application of various technologies by means of registration and the subsequent digital processing of the stress wave impulse arising during the explosion.

The second stage incorporated the experiment on the fragmentation uniformity in the rocks with different hardness for which the following model of research was developed. The direction of initiation was direct, inverse and counter. For each method of initiation, two holes with $36 \mathrm{~mm}$ diameter were drilled. As a blasting cartridge, we used ammonite No 6JV which was set various directions of initiation by ED-8E electrodetonator. After the blast, the mass was filled in with liquid epoxy with an additive of the special solvent preventing the epoxy from setting-up. During this period, the epoxy managed to fill all the cracks formed as a result of explosion. Having measured the length of cracks by the curvimeter and having determined the fissuring density (the relation of all cracks length to the area of the mass), we received the quantitative analysis of the result of real mining medium destruction depending on the direction of initiation. The obtained data allowed to draw the graphs that express dependence of density on the fissuring density in characteristic sections of models from the direction of initiation (Fig. 3).

The obtained values of fissuring density at various distances from the free surface allow to assess the extent of separate mass sites fragmentation under destruction and evaluate the uniformity of the medium fragmenting at various directions of initiation. In the graphs, the vertical axis refers to the values of fissuring density $\delta$, and the horizontal axis - to the distance from the studied cross-section to the free surface expressed in relative units by $L / d$ relation where $L$-distance from the cross-section to the free surface; $d$-diameter of the charge.

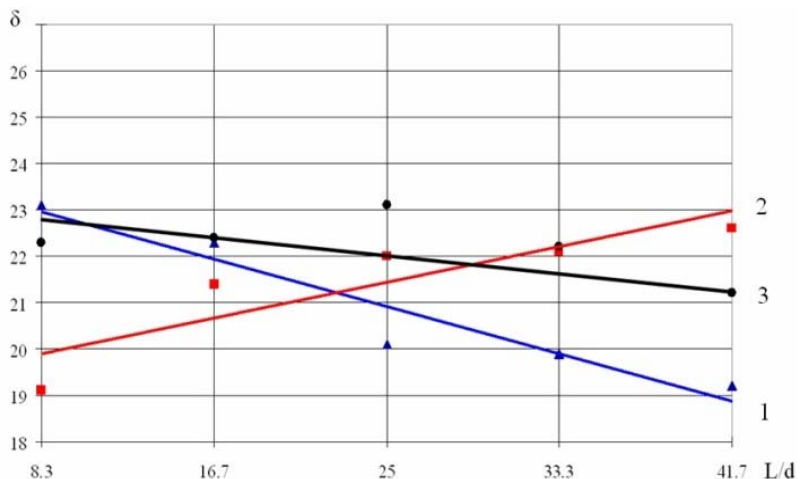

Figure 3. Dependence of fissuring density on the relative distance to the free surface during various ways of initiation in the rocks with different hardness: 1 -direct; 2 -inverse; 3 - counter

Analysis of the received dependences shows that for the rocks with different hardness and the depth of wells to 30 diameters it is most rational to apply counter initiation, and then - direct one. The worst indicators of hard streaks fragmentation are associated with application of wells of such depth in combination with inverse initiation. For the wells depth of more than $30 \mathrm{~d}$ it is necessary to apply the inverse initiation, then counter initiation, while it is rather unreasonable to use direct initiation. The extent of medium fragmentation increases during the inverse initiation with the increase in the depth of wells, and decreases during the direct and counter initiation.

Thus, it is established that in the rocks with different hardness it is rational to apply direct initiation of explosive charges to ensure uniform fragmentation. Hence, the high crushability of hard streaks is reached at the depth of wells equal 30 diameters.

As a result of the conducted complex research, we suggested a number of techniques how to blast the mass of rocks with different hardness including drilling of wells, determination (in the course of drilling) of the number and thickness of hard streaks, placement of a charge in the hole, stemming and detonation. The charge in the well is concentrated in the hard streak leaving an underdrilling. The charge is blown up by counter initiation with application of the intermediate detonators installed on the top and bottom boundaries of each streak. The illustration of the developed technique is presented in Figure 4.

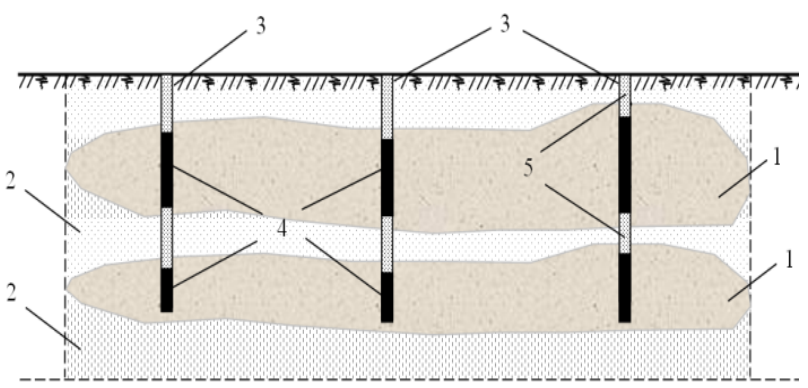

Figure 4. A method of destructing hard streaks in the mass of rocks: 1-hard streak; 2 -soft rocks; 3 -well; 4 -explosive; 5 - stemming 
According to the passport of drilling-and-blasting works, it is supposed to drill vertical holes and at the same time to define the number and thickness of hard streaks. For ensuring high-quality fragmentation of the rocks with different hardness, the explosive is placed in the hole along the partial thickness of the streak. Intermediate detonators are placed on the top and bottom boundaries of each streak, followed by stemming, subsequent simultaneous detonation with counter initiation and non-electric system of initiation.

Application of the developed technique in terms of concrete structural features of the mass of rocks with different hardness allows to receive the set extent of streaks fragmentation and the quality of mass preparation for various technological schemes of development with minimum material and power consumption.

The developed method of explosive destruction of the mass of rocks with different hardness has yielded economic effect of more than $581.7 \mathrm{mln}$ sum per $10.5 \mathrm{mln} \mathrm{m}^{3}$ of the shot down rock mass.

We developed the method of blasting the mass of rocks with different hardness based on the following stages. First additional cracks are cut above the hard streaks between the main borehole charges, with cumulative explosive charges placed in them and blown up simultaneously with the main borehole charges, which ensures high-quality fragmentation of rocks with different hardness presented by hard streaks, located in the top part of a bench in the zone of uncontrollable fragmentation.

\section{CONCLUSIONS}

The method of explosive destruction of rocks with different hardness using slot charges is realized by determination of hard streaks thickness in the course of holes drilling. The slots $0.8 \mathrm{~m}$ wide placed between holes have the depth equal to the depth of hard streaks occurrence. Explosive charges having the directed cumulative action are installed at the bottom of a slot. The slot and holes are filled with stemming, the main borehole blasts and additional slot-hole charges are blown up at the same time. Such design of slot-hole explosive charges allows to achieve uniform fragmentation of rocks with different hardness due to the directed use of blast energy on hard streaks located in the top part of the bench of sheet deposit with the difficult structure and reduces the specific consumption of explosives.

The developed method of blasting rocks with different hardness using slot-hole charges and stage-by-stage detonation is effective in difficult hydrogeological conditions and is implemented in the free industrial and economic zone "Navoiy" with economic effect of more than $12 \mathrm{mln}$ UZS per $17000 \mathrm{~m}^{3}$ of shot down rock mass.

Thus, the executed theoretical and experimental research aimed at development of scientific and technical fundamentals for explosive destruction of the mass of rocks with different hardness, and practical realization of their results on open mining operations of Navoiy mining and metallurgical company allowed to make an essential contribution to the solution of a topical scientific problem - effective use of explosion energy on hard streak when carrying out industrial explosions.

\section{ACKNOWLEDGEMENTS}

The paper did not originate under any project and no funding was raised.

\section{REFERENCES}

Norov, Y.D., Zairov, SH., \& Sattarov, U.B. (2013). Development Composition and Method for Producting Thermo Substance, With Elevated Detonate Properties. Mining Messenger of Uzbekistan, (2), 30-32.

Norov, Y.D., Bibik, I.P., \& Zairov, SH. (2016). Effective Management of the Drilling and Blasting Parameters According to the Criterion of the Quality of Blasted Rock Mass. Mining Journal, (1), 34-39.

Norov, Y.D., Zairov, SH., Xaydarov, O.B., \& Rustamov, O.I. (2016). Control the Collaps Of the Rocks Subject to the Energe of Emulsion Explosive. Mining Messenger of Uzbekistan, (1), 16-19.

\section{ABSTRACT (IN UKRAINIAN)}

Мета. Розробка способу вибухового руйнування міцних включень в масиві різноміцних гірських порід на основі встановлення закономірностей зміни радіуса дроблення міцних пропластков та щільності тріщиноутворення від відносної відстані до вільної поверхні при різних способах ініціювання в різноміцних гірських породах.

Методика. Теоретичні та експериментальні дослідження з розробки науково-технічних основ вибухового руйнування масиву різноміцних гірських порід, що дозволяють встановити зону ущільнення м’яких порід, що знаходяться між міцними включеннями.

Результати. Розроблені способи вибухового руйнування масиву різноміцних гірських порід впроваджені на кар'єрі Ташкура Джером-Сардарінского родовища фосфоритів Навоїйського гірничо-металургійного комбінату з отриманням економічного ефекту в розмірі 581.7 млн UZS на 10.5 млн м³ відбиваної гірської маси й у вільній індустріально-економічній зоні “Навої” з отриманням економічного ефекту в розмірі понад 12 млн UZS на

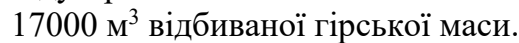

Наукова новизна. В результаті проведених комплексних досліджень запропоновано спосіб вибухового руйнування масиву різноміцних гірських порід, що включає буріння свердловин, визначення в процесі буріння кількості й потужності міцних пропластків, розміщення у свердловині заряду вибухової речовини, забійку та підривання.

Практична значимість. Реалізація результатів на відкритих гірничих роботах Навоїйського гірничометалургійного комбінату дозволила внести істотний внесок у вирішення актуального науково-практичного завдання - ефективного використання енергії вибуху по міцному пропластку при проведенні промислових вибухів.

Ключові слова: скельна порода, гірський масив, дроблення, різноміцні породи, поле напружень 


\section{ABSTRACT (IN RUSSIAN)}

Цель. Разработка способа взрывного разрушения крепких включений в массиве разнопрочных горных пород на основе установления закономерностей изменение радиуса дробления крепких пропластков и плотности трещинообразования от относительного расстояния до свободной поверхности при различных способах инициирования в разнопрочных горных породах.

Методика. Теоретические и экспериментальные исследования по разработке научно-технических основ взрывного разрушения массива разнопрочных горных пород, позволяющие установить зону уплотнения мягких пород, находящихся между крепкими включениями.

Результаты. Разработанные способы взрывного разрушения массива разнопрочных горных пород внедрены на карьере Ташкура Джерой-Сардаринского месторождения фосфоритов Навоийского горно-металлургического комбината с получением экономического эффекта в размере 581.7 млн UZS на 10.5 млн м ${ }^{3}$ отбиваемой горной массы и в свободной индустриально-экономической зоне “Навоий” с получением экономического эффекта в размере более 12 млн UZS на 17000 м $^{3}$ отбиваемой горной массы.

Научная новизна. В результате проведенных комплексных исследований предложен способ взрывного разрушения массива разнопрочных горных пород, включающий бурение скважин, определение в процессе бурения количества и мощности крепких пропластков, размещение в скважине заряда взрывчатого вещества, забойку и взрывание.

Практическая значимость. Реализация результатов на открытых горных работах Навоийского горнометаллургического комбината позволила внести существенный вклад в решение актуальной научнопрактической задачи - эффективного использования энергии взрыва по крепкому пропластку при проведении промышленных взрывов.

Ключевые слова: скальная порода, горный массив, дробление, разнопрочные породы, поле напряжений

\section{ARTICLE INFO}

Received: 20 February 2017

Accepted: 25 May 2017

Available online: 30 June 2017

\section{ABOUT AUTHORS}

Sherzod Zairov, Doctor of Technical Sciences, Associate Professor of the Mining Faculty, Navoiy State Mining Institute, 27a Janubiy St, 210100, Navoiy, Republic of Uzbekistan. E-mail: sher-z@mail.ru

Mukhabbat Ravshanova, Assistant Professor of the Mining Faculty, Navoiy State Mining Institute, 27a Janubiy St, 210100, Navoiy, Republic of Uzbekistan. E-mail: m_ravshanova@mail.ru

Sherzod Karimov, Student of the Mining Faculty, Navoiy State Mining Institute, 27a Janubiy St, 210100, Navoiy, Republic of Uzbekistan. E-mail: karimov20-13@,mail.ru 